\title{
Study of different temperature levels on radial growth and dry mycelial weight of Trichoderma spp. isolated from red gram based conservation agriculture ecosystem
}

\author{
N.M. PRABHAVATHI*1, Y.S. AMARESH ${ }^{1}$, M.K. NAIK ${ }^{1}$, S.B. MALLESH ${ }^{1}$ AND P.H. KUCHANUR ${ }^{2}$ \\ ${ }^{1}$ Department of Plant Pathology, University of Agricultural Sciences, RACHIPUR (KARNATAKA) INDIA \\ ${ }^{2}$ Department of Genetics and Plant Breeding, College of Agriculture, Bheemarayanagudi, GULBARGA (KARNATAKA) \\ INDIA
}

\begin{tabular}{|c|c|}
\hline Received & : 15.03.2014 \\
\hline Revised & : 25.08.2014 \\
\hline Accepted & : 06.09.2014 \\
\hline
\end{tabular}

KEY WORDS :

Trichoderma spp., Radial growth, Dry mycelia, Temperature
*Corresponding author:

Email: prabhavati4644@gmail.com

\begin{abstract}
Different temperatures and $\mathrm{pH}$ were taken to observe the radial growth and dry mycelial weight of Trichoderma spp. The radial growth of Trichoderma was maximum for all the four species i.e., T. harzianum, T. viride, T. hamatum and T. virens $(90,82,91.3$ and $85 \mathrm{~mm})$ at $30^{\circ} \mathrm{C}$, where it was minimum in four species at $40^{\circ} \mathrm{C}(30.70,35,22.53$ and $20 \mathrm{~mm})$, respectively and dry mycelium of T. harzianum $(1.05 \mathrm{mg})$, T. viride $(1.83 \mathrm{mg})$, T. hamatum $(2.42 \mathrm{mg})$ and T. virens $(0.82 \mathrm{mg})$ were maximum at $25^{\circ} \mathrm{C}$ whereas, the radial growth of four isolates were maximum at $\mathrm{pH} 6(90,88,92$ and $91 \mathrm{~mm})$ in T. harzianum, T. viride, T. hamatum and T. virens, respectively. At neutral $\mathrm{pH}$, radial growth of T. harzianum $(89 \mathrm{~mm}), T$. viride $(91$ $\mathrm{mm})$, T. hamatum $(89 \mathrm{~mm})$ and $T$. virens $(87 \mathrm{~mm})$ was minimum and dry mycelium weight of T. harzianum (729 mg), T. viride (1639.67 mg), T. hamatum $(798 \mathrm{mg})$ and T. virens $(583.67$ $\mathrm{mg}$ ) were maximum at $\mathrm{pH}$ 8. It was minimum at $\mathrm{pH} 4$ for $T$. harzianum $(120 \mathrm{mg}), T$. viride (257 mg), T. hamatum $(154 \mathrm{mg})$ and T. virens $(262.67 \mathrm{mg})$.
\end{abstract}

How to view point the article : Prabhavathi, N.M., Amaresh, Y.S., Naik, M.K., Mallesh, S.B. and Kuchanur, P.H. (2014). Study of different temperature levels on radial growth and dry mycelial weight of Trichoderma spp. isolated from red gram based conservation agriculture ecosystem. J. Plant Protec., 7(2) : 424-428. 